\title{
"Do socio-economic factors impede the engagement in online banking transactions? Evidence from Ghana"
}

\begin{tabular}{|c|c|}
\hline \multirow{5}{*}{ AUTHORS } & Abdul Bashiru Jibril iD https://orcid.org/0000-0003-4554-0150 \\
\hline & R https://www.researchgate.net/profile/Abdul_Bashiru_Jibril \\
\hline & Michael Adu Kwarteng (D https://orcid.org/0000-0002-6787-0401 \\
\hline & \multirow{2}{*}{$\begin{array}{l}\text { Miloslava Chovancová (D https://orcid.org/0000-0002-9244-9563 } \\
\text { Jurgen Bode }\end{array}$} \\
\hline & \\
\hline ARTICLE INFO & $\begin{array}{l}\text { Abdul Bashiru Jibril, Michael Adu Kwarteng, Miloslava Chovancová and Jurgen } \\
\text { Bode (2020). Do socio-economic factors impede the engagement in online } \\
\text { banking transactions? Evidence from Ghana. Banks and Bank Systems, 15(4), 1- } \\
\text { 14. doi:10.21511/bbs.15(4).2020.01 }\end{array}$ \\
\hline DOI & http://dx.doi.org/10.21511/bbs.15(4).2020.01 \\
\hline RELEASED ON & Wednesday, 21 October 2020 \\
\hline RECEIVED ON & Wednesday, 08 April 2020 \\
\hline ACCEPTED ON & Wednesday, 23 September 2020 \\
\hline & $(\mathrm{cc}) \overline{\mathrm{EY}}$ \\
\hline LICENSE & $\begin{array}{l}\text { This work is licensed under a Creative Commons Attribution } 4.0 \text { International } \\
\text { License }\end{array}$ \\
\hline JOURNAL & "Banks and Bank Systems" \\
\hline ISSN PRINT & $1816-7403$ \\
\hline ISSN ONLINE & $1991-7074$ \\
\hline PUBLISHER & LLC "Consulting Publishing Company "Business Perspectives" \\
\hline FOUNDER & LLC “Consulting Publishing Company "Business Perspectives" \\
\hline \multirow{2}{*}{ NUMBER OF REFERENCES } & 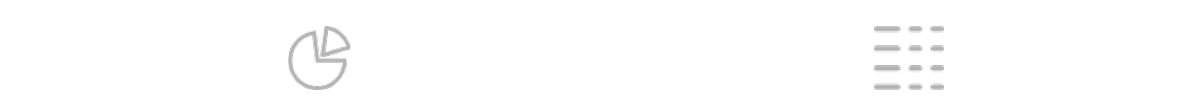 \\
\hline & NUMBER OF FIGURES \\
\hline 59 & 4 \\
\hline
\end{tabular}

(C) The author(s) 2022. This publication is an open access article. 


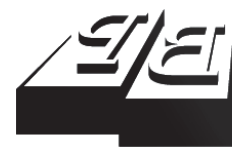

\section{BUSINESS PERSPECTIVES}

(O)

LLC "CPC "Business Perspectives"

Hryhorii Skovoroda lane, 10, Sumy, 40022, Ukraine

www.businessperspectives.org

Received on: $8^{\text {th }}$ of April, 2020 Accepted on: $23^{\text {rd }}$ of September, 2020 Published on: $21^{\text {st }}$ of October, 2020

(C) Abdul Bashiru Jibril, Michael Adu Kwarteng, Miloslava Chovancová, Jurgen Bode, 2020

Abdul Bashiru Jibril, Doctoral Researcher, Faculty of Management and Economics, Tomas Bata University in Zlin, Czech Republic. (Corresponding author)

Michael Adu Kwarteng, Senior Lecturer, Faculty of Management and Economics, Tomas Bata University in Zlin, Czech Republic.

Miloslava Chovancová, Associate Professor, Faculty of Management and Economics, Tomas Bata University in Zlin, Czech Republic.

Jurgen Bode, Professor, Department of Management Sciences, Hochschule Bonn-Rhein-Sieg University of Applied Sciences, Germany.

Abdul Bashiru Jibril (Czech Republic), Michael Adu Kwarteng (Czech Republic), Miloslava Chovancová (Czech Republic), Jurgen Bode (Germany)

\title{
DO SOCIO-ECONOMIC FACTORS IMPEDE
}

\section{THE ENGAGEMENT IN ONLINE BANKING TRANSACTIONS? EVIDENCE FROM GHANA}

\begin{abstract}
Researchers have long pondered on the online banking transaction adoption. Some of these studies focus primarily on the motivating factors that affect customers' intention to adopt/accept these services (technologies). However, research into the constraining factors, in particular socio-economic factors, barely exist in the literature, especially in the context of sub-Saharan Africa. Against this background, the paper seeks to fill in this gap by: (1) assessing the socio-economic factors impeding the engagement of e-banking transactions among retail bank customers in Ghana, and (2) examining the moderating effect of 'customer experience of Internet' on the identified factors that inhibit the engagement in online banking in Ghana. The paper used a quantitative research approach to obtain data from two leading Ghanaian banks. Out of the 450 questionnaires distributed, 393 were valid for analysis. Data were analyzed with the aid of PLS-SEM (partial least squares and structural equation modeling). Findings revealed that perceived knowledge gap and the price of digital devices were directly important to the intention to disembark on e-banking transactions among Ghanaian bank customers. Whilst customer experience (frequent use of the Internet), as a moderator variable, has a significant effect on the interaction between perceived knowledge gap and the intent to disembark on e-banking transactions; and finance charges and the intent to disembark on e-banking transactions. Study implications and directions for future research are discussed in the paper.
\end{abstract}

\section{Keywords}

JEL Classification

\section{INTRODUCTION}

The advent of Financial Technology (FinTech) in the 21st century is rapidly shifting the overall pattern of businesses (Nyangosi, Arora, \& Singh, 2009; Oliveira, Faria, Thomas, \& Popovič, 2014; R. Sharma, Singh, \& S. Sharma, 2020). Whilst the society and its socio-economic environment of individuals continue to be a key determinant of the development of the Internet usage (Saleem \& Higuchi, 2014) and for that matter, ICT. FinTech has come to stay. Owing to that, the advent of e-commerce is one of the utmost profitable changes that has transformed the trading of products and services over the Internet, especially within the banking sector (Boateng, Adam, Okoe, \& Anning-Dorson, 2016; Miniwatts Marketing Group, 2014). As a matter of fact, research on Internet banking has gained the attention of many notable stakeholders, including bankers, customers, financial regulators among others, so as to examine the repercussions of engaging in such kinds of transactions. This paper defined online banking as a way/process of banking in which all financial transactions are performed electronically over the Internet, either 
from the banking hall or at the comfort zone of a user. In other words, online banking (e-banking) enables banks, customers and other parties to manage accounts and undertake/make account transactions directly/indirectly with the bank in question via the Internet, this, according to Oertzen and OdekerkenSchröder (2019), Ofori, Boateng, Okoe, and Gvozdanovic (2017), is described as Internet banking. However, unwillingness on the part of a bank customer to engage in the Internet banking platform for a successful and easier financial transaction remains a major concern amongst several financial institutions, especially in developing countries (Nasri, 2011; Yiu, Grant, \& Edgar, 2007).

Research has shown that online transaction progress in the third world countries, in particular, in the sub-Saharan Africa, is comparatively very low (Jibril, Kwarteng, Pilik, Botha, \& Osakwe, 2020; Sharma, 2011). Therefore, this study spans socio-economic factors that influence the unwillingness to engage in e-banking transactions in a developing country, particularly in Ghana. The study argues that, given the rate of Internet penetration and diffusion in the market arena, the effect of customer initiation in adopting online transactions over the web may be significant to the banking sector and that some aversion to adopting the technology may, therefore, offer and explain how customers perceive online banking in a lower penetration Internet community where this study barely exists.

Until recently, studies on e-banking or online banking transactions have focused more on the motivating factors that drive the intent to adopt e-banking transactions, rather than the de-motivating factors that propel the action (see Rahi, Ghani, \& Ngah, 2019; Singh \& Malhotra, 1970; Tarhini, El-Masri, Ali, \& Serrano, 2016). However, in under-developed countries like Sub-Sahara economies, the factors associated with the former have not been explored and are still rudimentary in the literature in terms of both the engagement and disengagement situations. In this light, this study describes socioeconomic factors as the distinction between societal problems and economical situations. While societal factors here are associated with the societal impediment in line with the tendency to adopt online banking transactions (income, education, community safety, and social support), economic conditions refer to "situations associated with the wellbeing of the retail customer averting him/her to adopt an online banking transaction (e.g., income, employment, etc.)" (Nabareseh, Osakwe, Klímek, \& Chova, 2014).

Therefore, to examine the effects of both societal problems and economic scenarios averting a customer to engage in online banking transactions in a developing country while ensuring the willingness to make banking transactions via online, this research (1) investigates the socio-economic factors obstructing the engagement of online banking transactions based on the literature related to digital device prices, infrastructure, perceived financial cost/charge, and perceived knowledge gap and customer experience, and (2) examines the moderating effect of 'customer experience of Internet' on the identified factors that inhibit the engagement of online banking in Ghana.

The study informs e-banking practitioners (about the constraints) that potentially frustrate customers about what online banking entails and its relevance to banking institutions. Hence, this study propels financial institutions to strategically strengthen the usage and continuity of technological advancement as socio-economic factors (constraints) in the retail banking sector are concerned.

\section{LITERATURE REVIEW}

\subsection{Socio-economic factors and engagement in online banking transactions}

Generally, socio-economic factors as expressed by recent scholars (Garín-Muñoz et al., 2019; Kakar,
2020) consist of distinct variables that include: income, education, employment, community safety, and social supports, among other things, that can significantly affect a person's life in a given geographical area. However, within the framework of the online banking system, this concept refers to factors, either tangible or intangible, that support people in accepting/adopting the use of a 
new technology (for example, e-banking systems). While, with respect to studies done on information technology, several external and internal factors; such facilitating condition, perceived ease of use, perceived usefulness, perceived credibility, social influence, among other things, have been regarded as positive socio-economic factors that trigger people's intention to accept/engage in the new system (see Ajzen, 1991; Venkatesh \& Davis, 2000; Venkatesh et al., 2003). On the other hand, this study examines the conflicting issues of these aforementioned factors that persistently inhibit the engagement in e-banking transactions in the context of a developing country: a lack of support infrastructure, price of digital devices, perceived knowledge gap, perceived financial cost, and customer experience as the underlying research constructs.

\subsubsection{Infrastructure}

Facilitating condition, such as investment of infrastructure, is commonly noted as an important key driver of socio-economic development of every nation (Shankar \& Meyer, 2009), while studies have shown that the "quality, quantity, and accessibility of economic infrastructure in developing countries lag considerably behind" (Boateng et al., 2008) as compared to the developed world (see Jibril et al., 2020; Nwaiwu et al., 2020). In light of this, scaling up infrastructure investment or support systems is largely described as a key driver to speed up socio-economic growth and development, especially in the undeveloped economies (Awh \& Waters, 1974). In fact, many developing countries have been scaling up an infrastructure support system, mostly through public spending, as well as growing participation of the private sector (Nabareseh et al., 2014). Therefore, infrastructure gaps are still large in pursuing sustainable technological development, such as smart cities, e-payment, e-revenue mobilization, among others, and filling these gaps would help in the medium to longterm sustainability of innovation diffusion and successful technology adoption by the citizenry.

\subsubsection{Price of devices}

This refers to the unit price of the digital device in the electronic market. In other words, it means the value of the amount paid to acquire any electronic device (Esteve \& Machin, 2007) in order to have access to online transactions. In the developing world, since many citizens are leaving below the poverty line (Ali, 2016) or within the low-income bracket (Ali \& Langendoen, 2007), buying sophisticated devices (such as smartphones, tablets, notebook, etc.) at higher prices makes it difficult to access such income brackets. It is also important to acknowledge the concept of 'consumer rationality' in the field of consumer behavior. This concept reiterates the principle of demand, which suggests that low-income earners demand less of a product (good) when the price is high, and vice versa.

\subsubsection{Perceived financial cost}

Financial cost towards the adoption/engagement in online transactions refers to expenses associated with the online transaction. Thus, these are expenses incurred in buying or selling a good or service or even using an online platform for other intended purpose (Stein et al., 2005; Wu et al., 2014) such as money transfer and interbank transfer/deposit. Yu (2012), in his work, argued that potential users of electronic banking systems/transactions are quite skeptical with regard to the potential charges that may be attached due to services rendered by a bank. Nonetheless, since first-timers anticipate that they would be deducted from their deposit or whichever possible, this perceived transaction cost deters potential users from engaging in 'loos game transaction', especially in a low-income bracket group (Amegbe \& Osakwe, 2018).

As a matter of fact, bank customers (both online and off-line) are mostly not satisfied when it comes to a levy on transaction-related activities, especially when the perceived cost does not correspond to the expected service provided. However, as the new technology (e-banking transaction) comes with an associated cost, hence, they (banks) transfer the service charge/ cost on to the users (Sathye, 1999; Yiu et al., 2007), since the cost is a shared responsibility to both a bank and a customer in question (Thambiah et al., 2010). This suggests that a shift in charges to bank clients can potentially 
discourage them to engage in an online banking transaction.

\subsubsection{Perceived knowledge gap and customer experience}

The knowledge gap indicates the view that a person with a higher status in an economy/society is privy to information offered by the mass media, and vice versa (Wei \& Zhang, 2008). As a result, this variation in the society leads to an increased gap in knowledge between these two segments (higher and lower socioeconomic status). The acquisition of Internet knowledge (IK) comprises two broad dimensions that are relevant to the Internet users. These two dimensions of Internet knowledge have also been described in the literature as 'declarative knowledge and procedural knowledge' (Page \& Uncles, 2004). To this, knowledge dimension (aspects) describes "what people know about the Internet and what people can do using the Internet", whereas declarative knowledge, on the other hand, describes "how people are familiarized with specific Internet terms such as search, cookies, and browser, whereas procedural knowledge indicates people's understanding of how to perform relevant Internet tasks" (Page \& Uncles, 2004).

Though Internet knowledge is theoretically a distinctive construct, the limits between this concept (IK) and Internet experience have been largely examined in many technology acceptance model-related studies. However, the concept of experience often interchanges to mean knowledge; thus, the more familiar the user is with the usage, the more knowledgeable about the technology of interest, and vice versa. Again, this is evidence that the measurements of experience sometimes overlap with those of knowledge in the literature (see Bozionelos, 2004; Bradlow, Hoch, \& Hutchinson, 2002). However it also imperative to acknowledge that IK is quite different from Internet experience, even though the former suggest what one knows, whereas the latter suggests what one has completed. Against this background, the paper argues that people who have the same level of Internet experience may consequently have different levels of Internet knowledge.

\section{AIMS}

The purpose of this paper seeks to fill in the gap by:

1) assessing the socio-economic factors impeding the engagement in e-banking transactions among retail bank customers in Ghana; and

2) examining the moderating effect of 'customer experience of the Internet' on the identified factors that inhibit the engagement in online banking in Ghana.

To achieve the above goals, the paper puts forward the following hypotheses:

H1: Lack of infrastructure support in a developing country positively predicts the unwillingness of bank customers to engage in online banking transactions.

H2: High price of digital devices (tablet, smartphone, etc.) in a developing country with respect to low income earners positively predict the unwillingness of consumers to engage in online banking transactions.

H3: Financial (operating) costs charged by banks toward online banking transactions potentially trigger customers' unwillingness to engage in/adopt online banking transactions.

H4: Perceived knowledge gap in the Internetusage environment directly predicts customers' unwillingness to engage (adopt) in online banking transactions.

H5a: Customers' experience in Internet usage significantly moderates the relationship between perceived Internet knowledge gap and unwillingness to engage in online banking transactions.

H5b: Customers experience in Internet usage significantly moderates the relationship between perceived financial cost/charge and unwillingness to engage in online banking transactions.

To conclude, the paper has summarized the literature review in a proposed research model (see Figure 1) for further investigation and validation. 


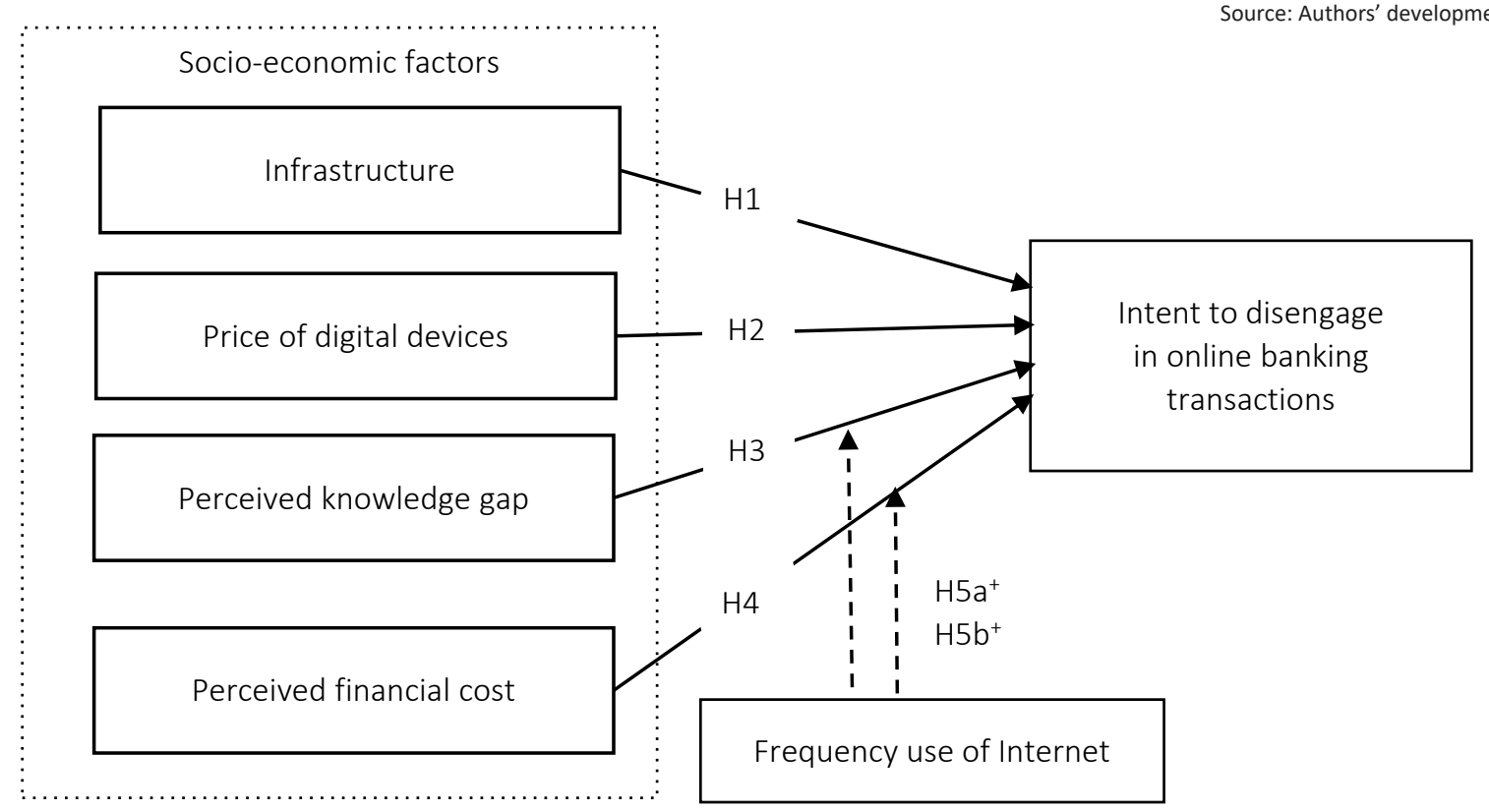

Direct effect

Moderating effect

Figure 1. Research model

\section{DATA AND METHODS}

\subsection{Measurement of constructs}

It is important to note that the measures of the constructs in this paper were adapted from the existing literature. Again, it is expedient to note that the indicators (a clear qualitative statement) were measured using a five-point Likert scale, with $1=$ completely disagree, $2=$ disagree, $3=$ neutral, $4=$ agree, and $5=$ completely agree. Table 2 presents construct indicators used for the investigation. This study adapted the following constructs in the literature: infrastructure (Nabareseh et al., 2014), perceived knowledge gap (Wei \& Zhang, 2008), price of a digital device (Esteve \& Machin, 2007), customer experience (Venkatesh et al., 2003; Venkatesh \& Zhang, 2010), perceived financial charges/costs (Stein et al., 2005; Wu et al., 2014), and intent to engage/disengage in e-banking transaction, (Ajzen, 1991; Ali, 2016). Also, see Table 2 for the definition of the variable for the respective constructs.

\subsection{Data collection and analytic technique}

This paper used both random and non-randomized sampling techniques for data extraction. First, a non-randomized sampling technique (non-probability) was adopted to select target banks (unit of analysis). This became necessary since the target banks were scattered all over the major administrative regions of Ghana, hence this technique is particularly convenient sampling technique (Etikan et al., 2016). Among other things, a technique was noted - accessibility, geographical proximity, willingness to participate, participants' accessibility to the researcher, and affordability in terms of cost (Etikan et al., 2016). Given this, the paper considered two leading commercial banks that have integrated online banking services in their routine operation, GCB bank and Eco bank Limited in Ghana. Secondly, after selecting the target banks, a randomized sampling technique was applied, specifically, the probability sampling technique. Thus, each customer of these selected banks is given the equal chance to be se- 
lected for the study irrespective of whether he/she is an off-line or on-line bank customer.

Data was finally collected using a structured questionnaire (both the intercept approach and online survey. With the intercept, it means the customers were trapped at the bank's premises, while the online survey link was sent to participants who requested it mainly because they were not ready at the time the field officials intercepted them at the designated points. Out of the 450 questionnaires distributed, 393 were valid for analysis. Though study subjects were pre-qualified to ensure their knowledge of online banking services with respect to their level of understanding of socio-economic factors affecting the engagement in Internet banking transactions. Data collection was carried out between November 2019 and February 2020. On average, it took seven minutes to fill the questionnaire. Table 1 shows a socio-demographic profile of the respondents to this study.

To analyze data, the partial least squares (PLS) approach is used since it focuses on the ex-

Table 1. Summary of socio-demographic characteristics of respondents

\begin{tabular}{|c|c|c|c|}
\hline \multicolumn{2}{|c|}{ Details of respondents } & \multirow{2}{*}{$\frac{\text { Frequency }}{232}$} & \multirow{2}{*}{$\begin{array}{c}\text { Percent (\%) } \\
59.0\end{array}$} \\
\hline Gondor & Male & & \\
\hline Gender & Female & 161 & 41.0 \\
\hline \multirow{5}{*}{ Age } & $18-25$ & 41 & 10.4 \\
\hline & $26-30$ & 133 & 33.8 \\
\hline & $31-35$ & 140 & 35.6 \\
\hline & $36-40$ & 55 & 14.0 \\
\hline & Above 40 & 24 & 6.1 \\
\hline \multirow{6}{*}{ Educational level } & Basic School (Primary School) & 0 & 0 \\
\hline & Secondary (High) School & 90 & 23.0 \\
\hline & Bachelor's/Undergraduate & 163 & 41.5 \\
\hline & Master's & 95 & 24.6 \\
\hline & $\mathrm{PhD}$ & 15 & 3.8 \\
\hline & Others & 30 & 7.6 \\
\hline \multirow{2}{*}{ Citizenship status } & Ghanaian & 369 & 93.9 \\
\hline & A foreign resident in Ghana & 24 & 6.1 \\
\hline \multirow{2}{*}{ Online visitation } & Yes & 345 & 87.8 \\
\hline & No & 48 & 12.2 \\
\hline \multirow{2}{*}{ Use of online banking services } & Yes & 197 & 50.1 \\
\hline & No & 196 & 49.9 \\
\hline \multirow{5}{*}{ The medium of Internet access } & Own Laptop & 130 & 33.1 \\
\hline & Home/Personal PC & 41 & 10.4 \\
\hline & School/Office PC & 56 & 14.2 \\
\hline & Smartphone/Mobile Phone & 143 & 3.6 \\
\hline & Cybercafé PC & 23 & 5.9 \\
\hline \multirow{6}{*}{ The frequency of Internet use } & Daily & 265 & 67.4 \\
\hline & Weekly & 61 & 15.5 \\
\hline & Once or twice in a month & 25 & 6.4 \\
\hline & Once or twice in 3 months & 10 & 2.5 \\
\hline & Few times in a year & 16 & 4.1 \\
\hline & Never & 6 & 1.5 \\
\hline \multirow{4}{*}{ Location } & $\begin{array}{l}\text { Accra metropolitan: } \\
\text { GCB Bank Ltd. } \\
\text { Ecobank Ghana }\end{array}$ & $\begin{array}{c}145 \\
90 \\
55\end{array}$ & $\begin{array}{l}39.9 \\
22.9 \\
14.0\end{array}$ \\
\hline & $\begin{array}{l}\text { Kumasi metropolitan: } \\
\text { GCB Bank Ltd. } \\
\text { Ecobank Ghana }\end{array}$ & $\begin{array}{c}141 \\
78 \\
63\end{array}$ & $\begin{array}{l}35.9 \\
19.8 \\
16.0\end{array}$ \\
\hline & $\begin{array}{l}\text { Sunyani Municipal: } \\
\text { GCB Bank Ltd. } \\
\text { Ecobank Ghana }\end{array}$ & $\begin{array}{c}107 \\
56 \\
51\end{array}$ & $\begin{array}{l}27.2 \\
14.2 \\
13.0\end{array}$ \\
\hline & Total (N) & 393 & 100.0 \\
\hline
\end{tabular}


plained variance of the criterion variable (Hair et al., 2017; Risher et al., 2019). Since this study is exploratory, the use of PLS is considered most appropriate by several technology marketing investigators (Amegbe \& Osakwe, 2018; Chen et al., 2019; Henseler et al., 2016; Jibril et al., 2019). This study used SmartPLS 3.2.9 to test research hypotheses.

\subsection{Test of the common method bias (CMB)}

Following the earlier works by P. M. Podsakoff et al. (2003), the paper emphasizes in the current survey questionnaire, especially in the header section (at the beginning of the ques- tionnaire), that 'there are no right or wrong answers to the questions asked'. The researchers proceeded to assure the respondents of their anonymity and were asked to freely quit from answering the questionnaire at their discretion. Regarding the qualitative measures used to address potential concerns about common method bias (CMB), the paper took inspiration from the recent suggestions in the PLS-SEM literature from Kock and Hadaya, (2018), hence, the research employed a full collinearity approach, in particular, a variance inflation factor (VIF), to examine the evidence of CMV. The results of this post-hoc estimate show that common method bias (CMB) is not a major concern since the computed VIFs (see Table 2) are less than three

Table 2. Cross-loadings and construct reliability and validity

\begin{tabular}{|c|c|c|c|}
\hline Construct & Items (operationalization of a construct) & Loadings & VIF \\
\hline \multirow{5}{*}{ Infrastructure } & $\begin{array}{l}\text { GOVSUP1: In my opinion, I think lack of government support infrastructure in } \\
\text { Information Communication Technology (ICT) sector negatively affect easy internet } \\
\text { accessibility. }\end{array}$ & 0.868 & 2.034 \\
\hline & $\begin{array}{l}\text { GOVSUP2: I think the inability of the government to create more awareness on the } \\
\text { benefits of ICT (INTERNET) usage for all citizens negatively affect online-related } \\
\text { transactions. }\end{array}$ & 0.893 & 2.518 \\
\hline & $\begin{array}{l}\text { GOVSUP3: I think lack/inadequate internet access to all areas in the country as well as } \\
\text { FREE WIFI in schools and recreation centres affect my willingness to engage in online- } \\
\text { related transactions. }\end{array}$ & 0.798 & 2.180 \\
\hline & $\begin{array}{l}\text { GOVSUP4: I think internet and other devices such as computers and smartphones } \\
\text { prices should be moderate to be afforded by giving subsidies to dealers/operators in } \\
\text { the Telcom industry. }\end{array}$ & 0.832 & 1.655 \\
\hline & \multicolumn{3}{|l|}{$C R=0.911, A V E=0.720, C A=0.873$} \\
\hline \multirow{6}{*}{$\begin{array}{l}\text { Intention to engage } \\
\text { in online banking }\end{array}$} & INTENT1: I would use Internet banking for purchasing a product/service & 0.887 & 3.636 \\
\hline & INTENT2: I would always consider using the Internet for my shopping & 0.780 & 2.886 \\
\hline & INTENT3: Given the chance, I would try to buy items online via Internet banking & 0.889 & 4.164 \\
\hline & INTENT4: In the future, I will most likely be using Internet banking for payments & 0.874 & 4.002 \\
\hline & INTENT5: Using Internet banking for transfer/deposit is something I would do & 0.850 & 3.490 \\
\hline & \multicolumn{3}{|l|}{$C R=0.932, A V E=0.734, C A=0.910$} \\
\hline \multirow{4}{*}{$\begin{array}{l}\text { Price of digital } \\
\text { device }\end{array}$} & PDD1: I would easily buy a digital device if I am offered a price discount & 0.874 & 1.974 \\
\hline & PDD2: I am generally concerned about the price of digital devices & 0.801 & 1.662 \\
\hline & $\begin{array}{l}\text { PDD3: The lower the price I get a digital device, the more I will engage/transact in } \\
\text { online banking }\end{array}$ & 0.862 & 1.678 \\
\hline & \multicolumn{3}{|l|}{$C R=0.883, A V E=0.716, C A=0.803$} \\
\hline \multirow{4}{*}{$\begin{array}{l}\text { Perceived } \\
\text { knowledge gap }\end{array}$} & $\begin{array}{l}\text { PKG/DG1: I will use Internet banking when I have adequate knowledge about its } \\
\text { usefulness }\end{array}$ & 0.978 & 5.417 \\
\hline & $\begin{array}{l}\text { PKG/DG2: I will engage in Internet banking transactions when I have adequate } \\
\text { knowledge about its convenience }\end{array}$ & 0.934 & 5.317 \\
\hline & $\begin{array}{l}\text { PKG/DG3: I will use Internet banking if I have much adequate knowledge about how to } \\
\text { use it }\end{array}$ & 0.959 & 5.826 \\
\hline & \multicolumn{3}{|l|}{$C R=0.970, A V E=0.916, C A=0.955$} \\
\hline \multirow{4}{*}{$\begin{array}{l}\text { Perceived } \\
\text { transaction cost }\end{array}$} & PTC1: I won't use an online transaction when the charging fee is high & 0.861 & 1.819 \\
\hline & PTC2: Engaging in Internet banking may attract some deduction from my bank account & 0.909 & 2.435 \\
\hline & PTC3: Using Internet banking would affect my deposit/savings negatively & 0.827 & 1.924 \\
\hline & $C R=0.900, A V E=0.751, C A=0.835$ & & \\
\hline
\end{tabular}

Note: $\mathrm{CR}=$ Composite reliability, $\mathrm{AVE}=$ Average variance extracted, $\mathrm{CA}=$ Cronbach alpha. 
(3) taking into account the maximum threshold of ten (10). Therefore, in this analysis, the concerns about $\mathrm{CMB}$ are minimal, hence the potential CMB concerns are low.

\section{RESULTS}

\subsection{Model assessment}

According to the relevance and key recommendations in the PLS literature by pioneering scholars (see Hair et al., 2014; Hair et al., 2017), the paper first assessed the convergent validity and subsequently the discriminant validity of the outer model using the SmartPLS 3.2.9 version of statistical software. According to the estimations from the rigorous analysis, the construct indicators' loadings are relatively larger than 0.7 , considering the threshold of 0.6 (see Bagozzi \& Yi, 1988). Table 2 has the constructs exhibiting high composite reliability scores, with average variance extracted (AVE) scores of constructs exceeding 0.5 , whiles the Cronbach alpha of the research constructs exceeded 0.7. Hence, the study constructs have exhibited convergent validity (see Table 2).

Moreover, to establish the discriminant validity, on the other hand, Fornell and Larcker's (1981) criterion was used to assess the presence of discriminant validity among the research constructs (Henseler et al., 2015). Findings from Fornell-Lacker's criterion indicated that constructs satisfy both basic and stringent assumptions and this, therefore, establishes discriminant validity. In particular, the values in the diagonal (in bold) of the Fornell-Lacker's table (see Table 3) indicate AVEs of the measured constructs and met the threshold of 0.5 (Fornell \& Larcker, 1981).

\subsection{Structural model}

After assessing the initial step in the PLS analysis, the structural parameters of the fitted model were evaluated. This study used different quality criteria to assess the model, namely adjusted $\mathrm{R}^{2}$ magnitude (strength) and statistical significance of path loadings. Meanwhile, far from the basic requirement in the current PLS reporting (Hair, Risher, Sarstedt, \& Ringle, 2019), the standardized root mean squared residual (SRMR) $=0.087$, and is acceptable if $<0.1$; this indicates a good fit between the data and the research model. Concerning the direct hypothetical relationships, the price of a digital device (PDD) and perceived knowledge gap (PKG), thus, confirming $\mathrm{H} 3$ and $\mathrm{H} 4$, respectively, has a significant relationship affecting the engagement of e-banking transactions among the sampled respondents. Whilst infrastructure support and perceived financial charges/costs (PFC) were not directly significant towards the intention to disengage in e-banking transactions, which disproved $\mathrm{H} 1$ and $\mathrm{H} 4$, respectively (see Table 4).

However, the moderation analysis of the structural model shows a significant relationship. Importantly, the paper considered customers' experience, in particular, their 'frequent use of the Internet' as a moderating variable, to determine the moderating effects on the interactions between PKG $\rightarrow$ INTENT and PFC $\rightarrow$ INTENT. Interestingly, there was a significant relationship between the two interactions, thus, confirming $\mathrm{H} 5 \mathrm{a}$ and $\mathrm{H} 5 \mathrm{~b}$, respectively, at a bootstrapping sample size of 999 with a T-test greater than 1.96 or P-value less than 0.05 .

In a nutshell, Table 4 presents the results of the structural model and, accordingly, the research findings. $\mathrm{R}^{2}$ shows that about $45 \%$ of variance in the dependent variable (intention) is explained by the independent variables in the research model.

Table 3. Discriminant validity test - Fornell-Larcker criterion

Source: Authors processing based on SmartPLS 3.2.9.

\begin{tabular}{l|c|c|c|c}
\hline \multicolumn{1}{c}{ Construct } & $\mathbf{1}$ & $\mathbf{2}$ & $\mathbf{3}$ & $\mathbf{4}$ \\
\hline Intent to disengage & 0.857 & - & - & $\mathbf{5}$ \\
\hline Perceived knowledge gap & 0.259 & 0.957 & - & - \\
Price of digital device & 0.390 & 0.325 & 0.846 & - \\
Perceived financial charge/cost & 0.148 & 0.463 & 0.247 & - \\
Infrastructure & 0.134 & 0.383 & 0.165 & - \\
\hline
\end{tabular}


Table 4. Hypothetical path analysis

Source: Authors processing based on SmartPLS 3.2.9.

\begin{tabular}{|c|c|c|c|c|c|}
\hline Hypothesis & Mean & S. D. & $\begin{array}{c}\text { Regression } \\
\text { coefficient (B) }\end{array}$ & T-value & Remarks \\
\hline \multicolumn{6}{|c|}{ Direct effect } \\
\hline (H1): INFRAST $\rightarrow$ INTENT & 0.086 & 0.059 & 0.087 & 1.470 & Not supported \\
\hline$(\mathrm{H} 2): \mathrm{PDD} \rightarrow \mathrm{INTENT}$ & 0.250 & 0.063 & 0.246 & 3.884 & Supported \\
\hline (H3): PFC $\rightarrow$ INTENT & 0.018 & 0.059 & 0.013 & 0.218 & Not supported \\
\hline (H4): PKG $\rightarrow$ INTENT & 0.191 & 0.055 & 0.192 & 3.499 & Supported \\
\hline \multicolumn{6}{|c|}{ Moderation effect } \\
\hline$(\mathrm{H} 5 a):$ Mod1 Freq-Internet-usage on KG $\rightarrow$ INTENT & -0.199 & 0.042 & -0.201 & 4.807 & Supported \\
\hline$(\mathrm{H} 5 \mathrm{~b}):$ Mod2 Freq-Internet-usage on FC $\rightarrow$ INTENT & -0.132 & 0.038 & -0.131 & 3.426 & Supported \\
\hline R-squared $\left(\mathrm{R}^{2}\right)$ INTENT $=0.445$ & & & & & \\
\hline
\end{tabular}

Note: $\mathrm{A}$ hypothesis is significant at T-value $>1.96$. PKG $=$ perceived knowledge gap, $\mathrm{PDD}=$ price of a digital device, $\mathrm{PFC}=$ perceived financial charges/costs, INFRAST = Infrastructure, and INTENT = intent to disengage.

\section{DISCUSSION}

Based on the results, the paper concludes that there is a significant impact of socio-economic factors on the advent of Fintech, in particular, e-banking transactions. It worth noting that FinTech would persistently emerge as a robust and global e-commerce platform/App that facilitates banks and other service providers, especially in the financial industry. This will help to initiate and offer users alternative consumption of innovative products and services (Denny, 1970; Rahi et al., 2019). The results show that PDD and PKG ( $\mathrm{H} 2$ and $\mathrm{H} 4$, respectively) have a significant effect on customers' inability to engage successfully in e-banking transactions in a developing country. This is consistent with previous findings from Ali (2016) and Thambiah et al.(2010). Tarhini et al. (2016) argued that the early slow pace of the e-commerce adoption and resistance with regards to online-related transactions are mainly attributed by knowledge gap and environmental factors affecting their adoption in developing countries where Ghana cannot be isolated so far as the study of technology adoption in a developing country is concerned. Also, Wei and Zhang (2008) argue that as per the rate of low-income earners and a high poverty rate among people from the less developed countries (LDC's), their purchasing power regarding the demand for electronic goods is relatively low, thus, affecting their inclination for digital devices such as smartphones, notebooks, etc. This assertion is in tandem with the current evidence from Ghanaian bank customers. Hence, the findings of this research largely reinforce the impression that these constructs potentially influence the engagement/disengagement in e-banking transactions, especially among low Internet penetration settings (Jibril et al., 2020).

Interestingly, INFTRAS and PFC ( $\mathrm{H} 1$ and $\mathrm{H} 3$ respectively) showed an insignificant determinant towards customers' inability to hook up on e-banking transactions. Consequently, the study suggests that the customers (thus, immediate beneficiaries) of the online banking system believe that there is an expected cost to be incurred while using such a service. Therefore, to their (customers) best of knowledge, the said operating charges are not a significant impediment in their quest to engage/disengage in e-banking transactions. This research is in contrast to the works of Awh and Waters (1974), Nabareseh et al. (2014), and Shankar and Meyer (2009). As per the analysis, respondents believe that the lack of an infrastructural support system plays a crucial role in the individuals' willingness to engage in online banking transactions.

Regarding the moderation analysis ( $\mathrm{H} 5 \mathrm{a}$ and $\mathrm{H} 5 \mathrm{~b})$, the result prove that there is a significant moderating effect on the interaction between PKG and INTENT to disembark on e-banking transactions given customer experience (frequency of the Internet use) as a moderating variable (Mattila \& Wirtz, 2001). Again, holding 'frequency use of Internet' as a moderator, there was a significant relationship between the interaction of PFC and INTENT to disembark on e-banking transactions among bank customers in Ghana. This sug- 
gests that customer experience (frequency of the Internet use) plays a significant indirect role in the technology acceptance and resistance. This finding is in line with Hanafizadeh et al. (2014) and Kang and Park (2014).

\subsection{Practical and theoretical implications of the study}

In practice, this study is a wake-up call for all players in the financial industry. Thus, bankers can rely on this current study to implement innovative ideas (strategy) to curtail the persistent constraints affecting bank customers in a developing country. It is worth noting that there is a need to intensify ICT literacy for organizations and consumers with regards to the relevance of e-commerce. Hence, financial outlets could take a leading role in practically training its members on how to educate their customers by offering them requisite knowledge on the relevance of online banking transactions so far as e-commerce is concerned. This training could be in the form of showcase (demonstrations) on video/broadcast on television and other social media outlets for the general public. This is quite important due to the growing level of technology development across the business enclave. Additionally, given the potential utilization of ICT in accelerating development in the country, the study suggests that governments, through their Ministry of Communication, Science and Technology, could deepen their national ICT policies that could ensure the sustainability of electronic transaction in order to bridge the digital gap between rural communities and urban areas. This intervention would consequently boost the technological advancement of an economy.

In theory, this research developed a framework to augment the extant literature by offering some empirical evidence of socio-economic factors such as perceived knowledge gap and price of digital devices as key important indicators influencing e-banking transactions among bank customers of a sub-Saharan African region. Besides, the study further deepens the growing discussion of Internet banking adoption and retention across the globe. The results are expected to provide a theoretical contribution to the area of retail banking and to understanding consumer behavior in the Ghanaian financial services industry. This paper also offers several avenues to the academic community by inviting other scholars to consider hidden variables that might have been overlooked. Notwithstanding, this study model (see Figure 1) is first of its kind that only concentrates on socio-economic factors that impede the engagement in e-banking transactions from a developing country perspective. Hence, it is a novel approach for the interested scholars to gauge the reapplication of the model in a similar academic context to ensure optimum use of the study model.

\section{CONCLUSION}

Several studies have extensively discussed the adoption of online banking transactions, whereas this study dwelled on the socio-economic factors that impede customers' intention to make use of online banking transactions in a developing country. The study used a quantitative approach to obtain data from two leading Ghanaian banks. Data were analyzed using PLS-SEM. Findings revealed that the perceived knowledge gap and epy price of digital devices were directly relevant to the intention to disembark on e-banking transactions among sampled customers of Ghanaian banks. Whilst customer experience (frequency of the Internet use), as a moderating variable, had a significant indirect effect on the relationship between perceived knowledge gap and the intent to disembark on e-banking transactions, as well as between finance charges and the intent to disembark on e-banking transactions.

The research finally suggested that banks and Fintech players use strategic mechanisms that could profitably influence customers to use their electronic financial services while limiting the potential rise of the above-mentioned constraints. However, the paper admonished that banks and government institutions could ensure massive infrastructural development in order to resolve the examined constraints so as to achieve the objective/purpose of e-banking transactions in the financial industry. Interestingly, 
and more importantly, this study is first of its kind in assessing socio-economic constraints, in particular, in Ghana, where internet penetration remains low relative to global average rate.

The study is not without limitations. First, the research considered only responses from the bank customers without considering the organizational perspective. Second, the study filtered out only five factors (constructs) from the literature, that is, perceived knowledge gap, price of digital device, perceived financial charges, customer experience, and infrastructure support system were identified as socio-economic factors impeding the engagement in e-banking transactions in Ghana. Third, the sample size of the study is relatively low in terms of the number of retail banks in Ghana, thereby affecting the generalization of the work. Last but not least is a single-based geographical study.

Therefore, future scholars are encouraged to consider research that integrates perspectives from both individual and organizational levels. Additional constructs that are considered as relevant socio-economic factors are also welcomed in future studies. This study also recommends future researchers to expand the sample size and the scope of the study, such as a comparative study between two sub-Sahara African countries. This will rather increase the reliability and validity of the research model.

\section{AUTHOR CONTRIBUTIONS}

Conceptualization: Abdul Bashiru Jibril, Michael Adu Kwarteng, Miloslava Chovancová, Jurgen Bode. Data curation: Abdul Bashiru Jibril, Michael Adu Kwarteng, Jurgen Bode.

Formal analysis: Abdul Bashiru Jibril.

Funding acquisition: Miloslava Chovancová, Jurgen Bode.

Investigation: Abdul Bashiru Jibril, Michael Adu Kwarteng.

Methodology: Abdul Bashiru Jibril.

Project administration: Michael Adu Kwarteng, Miloslava Chovancová.

Resources: Miloslava Chovancová.

Software: Abdul Bashiru Jibril.

Supervision: Michael Adu Kwarteng, Miloslava Chovancová, Jurgen Bode.

Validation: Abdul Bashiru Jibril, Michael Adu Kwarteng.

Visualization: Abdul Bashiru Jibril, Michael Adu Kwarteng, Jurgen Bode.

Writing - original draft: Abdul Bashiru Jibril.

Writing - reviewing \& editing: Abdul Bashiru Jibril, Michael Adu Kwarteng, Miloslava Chovancová, Jurgen Bode.

\section{ACKNOWLEDGMENT}

This work was supported by the Internal Grant Agency of Tomas Bata University under the Projects no. IGA/FaME/2019/008 and IGA/FaME/2020/002. The authors would like to extend their appreciation to Prof. Boris Popesko (Vice-dean for Research and Business Liaison) at the Faculty of Management and Economics for facilitating the financial readiness of this project.

\section{REFERENCES}

1. Ajzen, I. (1991). The theory of planned behavior. Organizational Behavior and Human Decision Processes, 50(2), 179-211. https://doi.org/10.1016/07495978(91)90020-T

2. Ali, M., \& Langendoen, K. (2007). TinyPC: enabling low-cost internet access in developing regions. Proceedings of the 2007 Workshop on Networked Systems for Developing Regions (pp. 1-6). https://doi. org/10.1145/1326571.1326576

3. Ali, T. (2016). Extending the UTAUT model to understand the customers' acceptance and use of internet banking in Lebanon: A structural equation modeling approach. Information Technology and People, 29(4), 830-849. https://doi.org/10.1108/ITP-022014-0034 
4. Amegbe, H., \& Osakwe, C. N. (2018). Towards achieving strong customer loyalty in the financial services industry: Ghanaian top banks' customers as a test case. International Journal of Bank Marketing, 36(5), 988-1007. https:// doi.org/10.1108/IJBM-06-20170120

5. Awh, R. Y., \& Waters, D. (1974). A discriminant analysis of economic, demographic, and attitudinal characteristics of bank charge-card holders: A case study. The Journal of Finance, 29(3), 973-980. https:// doi.org/10.1111/j.1540-6261.1974. tb01495.x

6. Bagozzi, R. P., \& Yi, Y. (1988). On the evaluation of structural equation models. Journal of the Academy of Marketing Science, 16(1), 74-94. https://doi. org/10.1007/BF02723327

7. Boateng, H., Adam, D. R., Okoe, A. F., \& Anning-Dorson, T. (2016) Assessing the determinants of internet banking adoption intentions: A social cognitive theory perspective. Computers in Human Behavior, 65, 468478. https://doi.org/10.1016/j. chb.2016.09.017

8. Boateng, R., Heeks, R., Molla, A., \& Hinson, R. (2008). Ecommerce and socio-economic development: conceptualizing the link. Internet Research, 18(5), 562-594. https://doi. org/10.1108/10662240810912783

9. Bozionelos, N. (2004). Socioeconomic background and computer use: the role of computer anxiety and computer experience in their relationship. International Journal of Human-Computer Studies, 61(5), 725-746. https://doi. org/10.1016/j.ijhcs.2004.07.001

10. Bradlow, E. T., Hoch, S. J., \& Hutchinson, J. W. (2002). An assessment of basic computer proficiency among active internet users: Test construction, calibration, antecedents and consequences. Journal of Educational and Behavioral Statistics, 27(3), 237-253. https://doi. org/10.3102/10769986027003237

11. Chen, X., Ran, L., Zhang, Y., Yang, J., Yao, H., Zhu, S., \& Tan,
X. (2019). Moderating role of job satisfaction on turnover intention and burnout among workers in primary care institutions: A cross-sectional study. BMC Public Health, 19(1), 1526. https://doi. org/10.1186/s12889-019-7894-7

12. Denny, S. (1970). The electronic commerce challenge. The Journal of Internet Banking and Commerce, 3(3). Retrieved from https://www. icommercecentral.com/openaccess/the-electronic-commercechallenge.php? aid $=38933$

13. Esteve, G., \& Machin, A. (2007). Devices to access internet in developing countries. MobEA $V$-Mobile Web in the Developing World, Colocated with the International World Wide Web Conference. Retrieved from http://www.ra.ethz.ch/CDstore/ www2007/www2007.org/workshops/paper_106.pdf

14. Etikan, I., Musa, S. A., \& Alkassim, R. S. (2016). Comparison of convenience sampling and purposive sampling. American Journal of Theoretical and Applied Statistics, 5(1), 1-4. https://doi. org/10.11648/j.ajtas.20160501.11

15. Fornell, C., \& Larcker, D. F. (1981). Evaluating structural equation models with unobservable variables and measurement error. Journal of Marketing Research, 18(1), 39-50. https://doi. org/10.1177/002224378101800104

16. Garín-Muñoz, T., López, R., Pérez-Amaral, T., Herguera, I., \& Valarezo, A. (2019). Models for individual adoption of eCommerce, eBanking and eGovernment in Spain. Telecommunications Policy, 43(1), 100-111. https://doi.org/10.1016/j. telpol.2018.01.002

17. Hair, J. F., Risher, J. J., Sarstedt, M., \& Ringle, C. M. (2019). When to use and how to report the results of PLS-SEM. European Business Review, 31(1), 2-24. Retrieved from https://www.emerald.com/ insight/content/doi/10.1108/EBR11-2018-0203/full/html

18. Hair, J. F., Sarstedt, M., Hopkins, L., \& G. Kuppelwieser, V. (2014). Partial least squares structural equation modeling (PLS-SEM) An emerging tool in business research. European Business Review, 26(2), 106-121. https://doi.org/10.1108/ EBR-10-2013-0128

19. Hair, J., Hollingsworth, C. L., Randolph, A. B., \& Chong, A. Y. L. (2017). An updated and expanded assessment of PLS-SEM in information systems research. Industrial Management \& Data Systems, 117(3), 442-458. https:// doi.org/10.1108/IMDS-04-20160130

20. Hanafizadeh, P., Keating, B. W., \& Khedmatgozar, H. R. (2014). A systematic review of Internet banking adoption. Telematics and Informatics, 31(3), 492510. https://doi.org/10.1016/j. tele.2013.04.003

21. Henseler, J., Hubona, G., \& Ray, P. A. (2016). Using PLS path modeling in new technology research: updated guidelines. Industrial Management \& Data Systems, 116(1), 2-20. Retrieved from https://www.emerald.com/ insight/content/doi/10.1108/ IMDS-09-2015-0382/full/html

22. Henseler, J., Ringle, C. M., \& Sarstedt, M. (2015). A new criterion for assessing discriminant validity in variancebased structural equation modeling. Journal of the Academy of Marketing Science, 43(1), 115135. https://doi.org/10.1007/ s11747-014-0403-8

23. Jibril, A. B., Kwarteng, M. A., Chovancova, M., \& Pilik, M. (2019). The impact of social media on consumer-brand loyalty: A mediating role of online basedbrand community. Cogent Business \& Management, 6(1), 1673640. Retrieved from https://www.tandfonline.com/doi/full/10.1080/2331 1975.2019.1673640

24. Jibril, A. B., Kwarteng, M. A., Pilik, M., Botha, E., \& Osakwe, C. N. (2020). Towards Understanding the Initial Adoption of Online Retail Stores in a Low Internet Penetration Context: An Exploratory Work in Ghana. Sustainability, 12(3), 854. https:// doi.org/10.3390/su12030854

25. Kakar, A. K. (2020). Investigating factors that promote time banking 
for sustainable community based socio-economic growth and development. Computers in Human Behavior, 107, 105623. https://doi.org/10.1016/j. chb.2018.07.034

26. Kang, D., \& Park, Y. (2014). based measurement of customer satisfaction in mobile service: Sentiment analysis and VIKOR approach. Expert Systems with Applications, 41(4), 10411050. https://doi.org/10.1016/j. eswa.2013.07.101

27. Kock, N., \& Hadaya, P. (2018). Minimum sample size estimation in PLS-SEM: The inverse square root and gamma-exponential methods. Information Systems Journal, 28(1), 227-261. https://doi. $\operatorname{org} / 10.1111 /$ isj. 12131

28. Martins, C., Oliveira, T., \& Popovič, A. (2014). Understanding the Internet banking adoption: A unified theory of acceptance and use of technology and perceived risk application. International Journal of Information Management, 34(1), 1-13. https://doi.org/10.1016/j. ijinfomgt.2013.06.002

29. Mattila, A., \& Wirtz, J. (2001). The Moderating Role of Expertise in Consumer Evaluations of Credence Goods. International Quarterly Journal of Marketing, 1, 281-292. Retrieved from https:// www.researchgate.net/publication/280803040_The_Moderating Role_of_Expertise_in_Consumer_ Evaluations_of_Credence_Goods

30. Miniwatts Marketing Group. (2014). Internet Growth Statistics - the Global Village Online. Global Village Online. Retrieved from https://www.internetworldstats. com/emarketing.htm

31. Nabareseh, S., Osakwe, C. N., Klímek, P., \& Chovancová, M. (2014). A comparative study of consumers' readiness for internet shopping in two African emerging economies: Some preliminary findings. Mediterranean Journal of Social Sciences, 5(23). Retrieved from http://www.richtmann.org/ journal/index.php/mjss/article/ view/4732

32. Nasri, W. (2011). Factors influencing the adoption of internet banking in Tunisia. International Journal of Business and Management, 6(8), 143-160. https://doi.org/10.5539/ijbm. v6n8p 143

33. Nwaiwu, F., Kwarteng, M. A., Jibril, A. B., Buřita, L., \& Pilik, M. (2020). Impact of Security and Trust as Factors that influence the Adoption and Use of Digital Technologies that Generate, Collect and Transmit User Data. ICCWS 2020 15th International Conference on Cyber Warfare and Security (pp. 363-372). Retrieved from https://search.proquest. com/docview/2390159752?pqorigsite $=$ gscholar

34. Nyangosi, R., Arora, J. S., \& Singh, S. (2009). The evolution of e-banking: a study of Indian and Kenyan technology awareness. International Journal of Electronic Finance, 3(2), 149-165. Retrieved from http://www.inderscience. com/offer.php?id=26357

35. Oertzen, A.-S., \& Odekerken-Schröder, G. (2019). Achieving continued usage in online banking: a post-adoption study. International Journal of Bank Marketing, 37(6), 1394-1418. https://doi.org/10.1108/IJBM-092018-0239

36. Ofori, K. S., Boateng, H., Okoe, A. F., \& Gvozdanovic, I. (2017). Examining customers' continuance intentions towards internet banking usage. Marketing Intelligence \& Planning, 35(6), 756-773. Retrieved from https://opus.lib.uts.edu.au/handle/10453/123675

37. Oliveira, T., Faria, M., Thomas, M. A., \& Popovič, A. (2014). Extending the understanding of mobile banking adoption: When UTAUT meets TTF and ITM. International Journal of Information Management, 34(5), 689-703. https://doi.org/10.1016/j. ijinfomgt.2014.06.004

38. Page, K., \& Uncles, M. (2004). Consumer knowledge of the World Wide Web: Conceptualization and measurement. Psychology \& Marketing, 21(8), 573-591. https:// doi.org/10.1002/mar.20023
39. Podsakoff, P. M., MacKenzie, S. B., Lee, J.-Y., \& Podsakoff, N. P. (2003). Common method biases in behavioral research: a critical review of the literature and recommended remedies. Journal of Applied Psychology, 88(5), 879903. https://doi.org/10.1037/00219010.88.5.879

40. Rahi, S., Ghani, M. A., \& Ngah, A. H. (2019). Factors propelling the adoption of internet banking: the role of E-Customer service, Website design, brand image and customer satisfaction. International Journal of Business Information System, 33(4), 1-21. https://doi.org/10.1504/ IJBIS.2020.105870

41. Saleem, A., \& Higuchi, K. (2014). Globalization and ICT innovation policy: Absorption capacity in developing countries. 16th International Conference on Advanced Communication Technology, (pp. 409-417). IEEE. https://doi.org/10.1109/ ICACT.2014.6779200

42. Sathye, M. (1999). Adoption of Internet banking by Australian consumers: an empirical investigation. International Journal of Bank Marketing, 17(7), 324-334. https://doi. org/10.1108/02652329910305689

43. Shankar, V., \& Meyer, J. (2009). The internet and international marketing. In M. Kotabe and K. Helsen (Eds.), The SAGE Handbook of International Marketing (Chapter 23). https:// doi.org/10.4135/9780857021007. n23

44. Sharma, H. (2011). Bankers' perspectives on e-banking and its challenges: evidence from North India. IUP Journal of Bank Management, 10(4), 61-70. Retrieved from https://econpapers. repec.org/article/icficfbm/v_3a1 0_3ay_3a2011_3ai_3a4_3ap_ 3a61-70.htm

45. Sharma, R., Singh, G., \& Sharma, S. (2020). Modelling internet banking adoption in Fiji: A developing country perspective. International Journal of Information Management, 53, 102116. Retrieved from http://repository.usp.ac.fj/12151/ 
46. Singh, B., \& Malhotra, P. (1970). Adoption of Internet banking: An empirical investigation of Indian Banking Sector. The Journal of Internet Banking and Commerce, 9(2). Retrieved from https://www. semanticscholar.org/paper/Adoption-of-Internet-Banking\%3AAn-Empirical-of-Singh-Malhotra/ f966c6b047e56567395328d6b0c4a030b9d04ec2

47. Stein, D. S., Wanstreet, C. E., Calvin, J., Overtoom, C., \& Wheaton, J. E. (2005). Bridging the transactional distance gap in online learning environments. The American Journal of Distance Education, 19(2), 105-118. https:// doi.org/10.1207/s15389286ajde1902_4

48. Tarhini, A., El-Masri, M., Ali, M., \& Serrano, A. (2016). Extending the UTAUT model to understand the customers' acceptance and use of internet banking in Lebanon: A structural equation modeling approach. Information Technology \& People, 29(4), 830-849. https:// doi.org/10.1108/ITP-02-2014-0034

49. Thambiah, S., Eze, U. C., Tan, K. S., Nathan, R. J., \& Lai, K. P. (2010). Conceptual framework for the adoption of Islamic retail banking services in Malaysia. Journal of Electronic Banking Systems, 2010(1), 1-10. Retrieved from https://ibimapublishing.com/articles/JEBS/2010/750059/750059.pdf

50. Venkatesh, V. (2000).

Determinants of perceived ease of use: Integrating control, intrinsic motivation, and emotion into the technology acceptance model. Information Systems Research, 11(4), 342-365. https://doi. org/10.1287/isre.11.4.342.11872

51. Venkatesh, V., \& Davis, F. D. (2000). A theoretical extension of the technology acceptance model: Four longitudinal field studies. Management Science, 46(2), 186-204. https://doi.org/10.1287/ mnsc.46.2.186.11926

52. Venkatesh, V., \& Zhang, X. (2010). Unified theory of acceptance and use of technology: US vs. China. Journal of Global Information Technology Management, 13(1), 5-27. https://doi.org/10.1080/1097 198X.2010.10856507

53. Venkatesh, V., Morris, M. G., Davis, G. B., \& Davis, F. D. (2003). User acceptance of information technology: Toward a unified view. MIS Quarterly, 27(3), 425-478. https://doi.org/10.2307/30036540

54. Wei, L., \& Zhang, M. (2008). The impact of Internet knowledge on college students' intention to continue to use the Internet. Information Research: An International Electronic Journal, 13(3). Retrieved from http://www. informationr.net/ir/13-3/paper348.html

55. Wu, L.-Y., Chen, K.-Y., Chen, P.-Y., \& Cheng, S.-L. (2014). Perceived value, transaction cost, and repurchase-intention in online shopping: A relational exchange perspective. Journal of Business Research, 67(1), 27682776. https://doi.org/10.1016/j. jbusres.2012.09.007

56. Yee-Loong Chong, A., Ooi, K.B., Lin, B., \& Tan, B.-I. (2010). Online banking adoption: an empirical analysis. International Journal of Bank Marketing, 28(4), 267-287. https://doi. org/10.1108/02652321011054963

57. Yiu, C. S., Grant, K., \& Edgar, D. (2007). Factors affecting the adoption of Internet Banking in Hong Kong implications for the banking sector. International Journal of Information Management, 27(5), 336-351. https://doi.org/10.1016/j.ijinfomgt.2007.03.002

58. Yousafzai, S. Y., Pallister, J. G., \& Foxall, G. R. (2003). A proposed model of e-trust for electronic banking. Technovation, 23(11), 847-860. Retrieved from https://www.researchgate.net/ publication/263656356_A_proposed_model_of_e-trust_for_electronic_banking

59. Yu, C.-S. (2012). Factors affecting individuals to adopt mobile banking: Empirical evidence from the UTAUT model. Journal of Electronic Commerce Research, 13(2), 104. Retrieved from https:// www.semanticscholar.org/paper/ Factors-Affecting-Individualsto-Adopt-Mobile-from-Yu/2a3e$4 a 3024 b f c 4 d f 27 d b 07 a 1 d-$ 48f77a6f371b0c3 